\title{
Akademski kapitalizam i uloga sociologije
}

Mirko PETRIĆ

Odjel za sociologiju, Sveučilište u Zadru

mpetric@unizd.hr

- Richard Münch. Akademischer Kapitalismus: Über die politische Ökonomie der Hochschulreform. Berlin: Suhrkamp, 2011, 459 str.

U uvodu svog priručnika o kulturnim studijima, Dean Duda ustvrdio je da je to područje istraživanja ujedno i »veoma zahvalna kritička pedagogija, posebice u kontekstu u kojemu se teško shvaća da osim što živimo u Hrvatskoj, živimo i u kapitalizmu (Duda, 2002: 5). Desetak godina kasnije, jasno je da posljedice globaliziranoga kapitalističkog poretka u kojemu živimo vrlo izravno osjeća sve više prethodno možda neosviještenih ljudi. No to još uvijek ne znači da su sposobni artikulirati kritičku poziciju, čak i ondje gdje bi se to najviše očekivalo: u visokom školstvu i akademskoj zajednici.

Ne može se, doduše, reći da u tom kontekstu u nas nije bilo reakcija na pojavu koju Richard Münch naziva »akademskim kapitalizmom« (Münch, 2011a), no stoji i to da su one uglavnom bile nadahnute neposrednom interesnom ugroženošću pojedinih »dionika« ili su pak problematici pristupale izrazito sektorski, u duhu današnje uznapredovale parcelizacije znanja u društvenim i humanističkim znanostima. Ne samo u hrvatskom kontekstu, rijetki su radovi koji pokušavaju podjednako znanstveno i kritički problematizirati danas dominantan način organizacije visokog školstva i znanstvene djelatnosti.

U tom smislu, recentna Münchova knjiga Akademski kapitalizam: o političkoj ekonomiji reforme visokog školstva (Münch, 2011a), iznimno je vrijedan doprinos raspravama na temu koje se već neko vrijeme odvijaju diljem Europe. Isto vrijedi i za dvije njegove ranije knjige, s naslovima Akademska elita: o društvenoj konstrukciji znanstvene izvrsnosti (Münch, 2007) te Globalne elite, lokalni autoriteti: obrazovanje i znanost pod režimom PISA-e, McKinseya \& Co. (Münch, 2009c).

Pritom valja napomenuti da uvjerljivosti i pouzdanosti Münchovih izvoda u raspravama o posljedicama globalizacije visokog školstva pridonosi i to što se u desetljeću koje je prethodilo njegovu umirovljenju na Sveučilištu u Bambergu (2013.) intenzivno bavio i temama povezanim s razvitkom politike i gospodarstva 
u uvjetima »slobodne trgovine« i zamjene države blagostanja »liberalnom natjecateljskom državom« (Münch, 2008, 2009a, 2011b). Takav istraživački interes i glasovita Münchova sociološka akribičnost čine njegove argumente u raspravi o reformi visokog školstva ipak znatno utemeljenijima nego što su to bili oni izloženi u polemičnom Liessmannovu eseju na temu (Liessmann, 2006), koji je nakon prijevoda (Liessmann, 2008) bio iznimno zapažen i u hrvatskoj akademskoj zajednici.

Naime, ondje gdje se Liessmann oslanja na kapital vlastite humanističke načitanosti i na njemu zasnovane dnevnopolitičke intuitivnosti, Münch provodi detaljne analize utemeljene u empirijskom materijalu. Uza sve podatke, dijagrame i sociološke kontekstualizacije terminologije koje nalazimo na 380 stranica njezinog glavnog teksta, Münchovoj publikaciji pridodano je i poglavlje od 50 stranica posvećeno »statističkim analizama natjecanja u akademskoj performativnosti ${ }^{1}{ }^{1}$ kojem slijedi vrlo iscrpna i tematski raznorodna bibliografija od čak 420 jedinica. $^{2}$

Iluzija o pravednoj raspodjeli. Nakon svih tih analiza teško je osporiti uvjerljivost Münchovoj konstataciji središnje illusio bourdieuovski shvaćenog polja znanosti, prema kojoj se sredstva za istraživanja raspodjeljuju u skladu s performativnošću pojedinih istraživača i skupina. Umjesto toga, prema autoru, riječ je o konstrukciji znanstvene izvrsnosti i elitnih centara kroz društveno isključivanje drugih aktera, što na koncu dovodi do osiromašivanja znanja i smanjenja društvene korisnosti istraživačke djelatnosti.

Prema Münchu, sve češći govor o »tržištu«, »natjecanju« i »vođenju izlaznih rezultata« znanstvenog istraživanja sociološki se može interpretirati kao naivan. Takav stav, uz statističke analize, dokumentira i bourdieuovskom interpretacijom tendencija u području te navođenjem zaključaka drugih autora koji su se ranije bavili istim problemom. Navodi tako poznatu Bourdieuovu tvrdnju prema kojoj preko dvije stotine godina postojanja elitnih škola nije Francuskoj donijelo ni znanstvenu ni gospodarsku korist, a pogotovo nije donijelo korist društvu u cjelini. Isto, iznosi dalje Münch, u Velikoj Britaniji vrijedi za Oxford i Cambridge, koji zapravo omogućuju održanje elitnih struktura, a da se to ne pretvara u opću društvenu korist. ${ }^{3}$

\footnotetext{
${ }^{1}$ Pri pripremi teksta tog dodatka autoru je pomogla Briggite Münzel. Vincent Gengnagel prikupio je podatke o profesionalnim mrežama u polju povijesti. Christian Baier priredio je deskriptivnu statistiku i obavio regresijske analize objava po znanstveniku u poljima kemije, fizike i biologije, kao i analizu profesionalnih mreža u polju povijesti. Christian Dressel obavio je regresijske analize ulaganja, reputacije i znanstvenog financiranja u poljima kemije, fizike i biologije, a Len Ole Schäfer obavio je isti posao za sveučilišta i za polje povijesti.

${ }^{2}$ Bibliografske jedinice izložene na 28 stranica publikacije obradio je Alexander Dobeson.

${ }^{3} \mathrm{U}$ tom je smislu zanimljiva i Münchova analiza koja pokazuje da svoju aktualnu rangiranost na Šangajskoj listi, gdje se pojavljuju kao rijetka visoko rangirana europska sveučilišta, Oxford i Cambridge zapravo duguju znanstvenim uspjesima (Nobelovim nagradama) ostvarenim prije 1979. godine te slučajnosti što znanstvenici zaposleni na tim sveučilištima pišu na engleskom jeziku. Potonje im daje vidljivost u imperijalnom, a zapravo provinci-
} 
Slijedeći Lenhardta (2005), navodi dalje da znanost u Sjedinjenim Američkim Državama nije uspješna zbog sveučilišta poput Harvarda, Princetona, Yalea i drugih sličnih, nego unatoč njihovu izdvojenom statusu: naime, u zemlji postoji još dovoljno drugih sveučilišta (približno 150) koja - u općenito natjecateljskom sustavu - mogu kao konkurenti stvarati podlogu za uspješnost. S druge pak strane, spomenuta su »elitna« sveučilišta suodgovorna za proizvođenje društvene strukture obilježene velikim nejednakostima i uznapredovalim dezintegracijskim procesima (Karabel, 2005; Douglas, 2007; Soares, 2007).

Opisanom modelu Münch suprotstavlja »klasično razumijevanje«, prema kojem bi rezultati znanstvenih istraživanja trebali biti svima dostupni kao kolektivno dobro. Ti se rezultati mogu koristiti i dalje unapređivati na bilo kojem mjestu na svijetu: štoviše, za raznovrsnost, kreativnost i otvorenost znanstvenog istraživanja poticajno je da su mjesta proizvodnje znanja široko rasprostranjena i da među istraživačima - barem u idealnom smislu riječi - vlada potencijalna jednakost prilika. No, suvremena inovacijska politika ide upravo u suprotnom smjeru, koji znanost izjednačava s primijenjenim industrijskim istraživanjima, a znanje nastoji što dulje zadržati tajnim i patentirati u poduzetničke svrhe. Taj je pristup podjednako fatalan za znanost samu, kao i za društveni razvoj koji bi se trebao na njoj zasnivati.

Prema autorima koji su se detaljno bavili temom, aktualan naglasak na povezivanju znanosti i industrije ni u kojem slučaju ne vodi kvaliteti novih spoznaja (Gibbons i dr., 1994; Etzkowitz, 2003; Rhoades i Slaughter, 2006). Münch takvu preobrazbu znanosti i njezino sljubljivanje $\mathrm{s}$ industrijom vidi kao rezultat nove koalicije prirodoznanstveno i tehnički usmjerene znanstvene elite s profitno usmjerenom globalnom gospodarskom elitom. Takva pak koalicija vodi načinu razmišljanja tipičnom za industrijsku proizvodnju samu: usmjerena je na postizanje monopolne rente koja nastaje kad se ovlada subjektima umreženim u proizvodnju. No, ne vidi se da takvo umreženje u trajnu strukturu učinkovito priječi daljnji razvoj znanosti, jer vodi samo u jednom smjeru i uklanja raznovrsnost potrebnu da bi se proizvodilo novo znanje i brzo odgovorilo na nove izazove.

jalnom, časopisnom kompleksu zasnovanom na citatima radova na engleskom jeziku koje objavljuju izdavači inkorporirani uglavnom u SAD-u i Velikoj Britaniji. Aktualnom časopisnom imperijalizmu valja pritom pridružiti i povijesnopolitički, kojemu autori iz Velike Britanije mogu zahvaliti povlašten citatni položaj u zemljama Commonwealtha. Kad je o Nobelovim nagradama riječ, one su u Velikoj Britaniji skoncentrirane u znatno manjem broju ustanova nego što je to slučaj u Njemačkoj, ali i u Sjedinjenim Američkim Državama. Ta koncentracija efektivno uskraćuje razvoj cjelokupnoj znanstvenoj zajednici u toj zemlji, što ne vodi povećanju kvalitete, nego upravo suprotno. Nakon skoka šezdesetih i sedamdesetih godina 20. stoljeća, broj se Nobelovih nagrada u Velikoj Britaniji stoga smanjuje. U Francuskoj, zemlji također poznatoj po isticanju »elitnih ustanova«, ukupan broj Nobelovih nagrada znatno je manji nego u Njemačkoj i u Velikoj Britaniji, podjednako u razdoblju prije i poslije Drugoga svjetskog rata. 
»Izvrsnost« kao put prema periferiji. Münch je, u ovom kontekstu, osobito kritičan prema njemačkoj »inicijativi za izvrsnost« (Exzellenzinitiative) i njezinoj usmjerenosti na stvaranje »elitnih sveučilišta«. Takva je inicijativa, dakako, u suprotnosti s njemačkom tradicijom prema kojoj je ideal bio ravnomjerna raspodjela kvalitete širom akademskog prostora. Novi naglasak na »izvrsnosti«, prema Münchu, za Njemačku znači da će se željena »elitnost« stvoriti tek desetljećima dugim procesom akumulacije simboličkog kapitala zasnovanom na društvenom isključivanju brojnih današnjih aktera. Nadalje, kod »inicijative za izvrsnost« osobito je pogubno to što potiče izvrsnost »ustanova« a ne pojedinačnih istraživača i istraživačica: takav pristup vodi gotovo neizbježnoj tendenciji stvaranja kartela i oligarhija, u znatno većoj mjeri nego kad je riječ o financiranju individualnih istraživačkih napora.

$\mathrm{Na}$ koncu, takvo se dokidanje njemačke tradicije federalnog pluralizma, koju su na nacionalnoj razini poštovale obrazovne i sindikalne elite, pokazuje kontraproduktivnim u novom, transnacionalnom okviru: čak i ako se omanja skupina njemačkih sveučilišta uspije približiti globalnom znanstvenom oligopolu, značit će to samo prestiž za te ustanove i njihove voditelje. Na nacionalnoj razini doći će ne samo do gubitka znanstvene kreativnosti, raznovrsnosti i inovativnosti, nego i do gubitka uloge društvene integrativnosti koju je sa sobom nosio prethodno dominantni njemački federalni model (Hartmann, 2006). Nova koalicija »staromodne« profesorske oligarhije, koja se drži vlastitih povlastica iz prethodnog vremena, s globalnom gospodarskom elitom, stavlja proizvodnju znanja u Njemačkoj u kontekst novoga globalnog diferenciranja na središte i periferiju, što se pokazuje upravo fatalnom putanjom budućih razvoja u području (usp. Beyer, 2006).

Poruke poluperiferiji. Ako ta tvrdnja stoji za znanstveni potencijal zemlje veličine i akademske tradicije kakvu ima Njemačka, nad njom bi se svakako trebale zamisliti i obrazovne vlasti i akademska zajednica svake male zemlje na poluperiferiji. I drugi dijelovi Münchove knjige, sastavljene od prerađenih materijala iz čak jedanaest prethodno objavljenih članaka, svakako bi iznenadili sve one koji se pri razmatranju tematike ravnaju prema priopćenjima »međunarodnih financijskih ustanova« i objavama u dnevnom tisku koje ih zatim propagandistički reproduciraju. Münch dokumentirano i argumentirano dovodi u pitanje sva opća mjesta na kojima se takve objave zasnivaju, u rasponu od važnosti rangiranosti sveučilišta na listama poput Šangajske do mogućnosti stvarnog poboljšanja akademske kvalitete na temelju evaluacijskih i akreditacijskih mehanizama zasnovanih na »strateškom upravljanju« i »menadžerskoj kontroli«.

Valja pritom još jednom napomenuti da autorova polemičnost nije nalik onoj koju je pokazao Liessmann (2006) ili kakva odlikuje brojne opozicijske inicijative na europskim sveučilištima. Prvi cilj Münchova uključivanja u raspravu o znanosti i visokom školstvu jest sociološko rasvjetljivanje sastavnica aktualnih procesa. Sigurno je da njegovi izvodi potom mogu poslužiti i u dnevnopolitičkim raspravama, kao i to da bi njihova težina - upravo zbog autorova izrazito analitičkog 
pristupa - u takvim raspravama mogla biti i veća od »buke i bijesa« ozlojeđenih akademskih zajednica.

Novo javno upravljanje znanošću. Münchu je jasno da je model novog upravljanja javnim resursima (New Public Management), u vremenu koje je proteklo od »konzervativne revolucije« osamdesetih godina prošlog stoljeća do danas, postao prevladavajući model racionalnoga, ciljno usmjerenog djelovanja javnih ustanova, upravo kao što to tvrde Lane (2000) i Gruening (2001). ${ }^{4}$

Danas se s pravom može reći da je taj model postao dijelom globalne kulture i obvezuje ne samo nacionalne države i organizacije, nego i individualne aktere. Prevladava i u akademskom svijetu, štoviše, autoritet znanosti - kao pretpostavljene pogonske sile gospodarskog i društvenog napretka - daje mu osobit legitimitet i služi kao poluga normativnog pritiska na političare i javnu upravu. Vlade koje se pokušaju suprotstaviti tom pritisku, izlažu se riziku optužbi za neodgovorno ponašanje i nelegitiman otpor znanstveno utemeljenoj racionalizaciji javne uprave.

Stoga pretpostavke novog modela upravljanja javnim resursima - unatoč mjestimičnim otporima - prihvaćaju političke i upravne elite diljem svijeta: na koncu se može reći da on pokreće doista globalno izomorfne procese u različitim područjima, pa tako i znanosti i visokom školstvu. Drugim riječima, da bismo se danas uopće izložili znanstvenoj prosudbi i zadržali legitiman status, neizbježno ćemo se susresti s nekim aspektom ili postulatom »nove javne uprave«.

Natjecanje bez tržišta. No, to ne znači - kao da cijelom svojom knjigom poručuje Münch - da bi akademska zajednica, u borbi između svoje tradicionalne »unutarnje slobode« i aktualnoga »vanjskog određivanja ciljeva«, trebala bez ostatka pristati na nove kriterije, pogotovo stoga što analiza pokazuje da njihovi realni učinci izmiču kontroli i idu u smjeru upravo suprotnom od proklamiranoga. Sustav »novoga javnog upravljanja« znanošću, naime, u brojnim svojim aspektima implicira da se strukturni deficiti pokušavaju otkloniti vanjskom kontrolom, što je poduhvat unaprijed osuđen na neuspjeh.

Dublji uzrok takvom stanju jest navodno »neoliberalno« podvrgavanje svih funkcionalnih područja društva zakonima tržišta. No, suprotno tim proklamacijama, analize pokazuju da je »strateško vođenje izlaznih rezultata« zapravo bliže komandno vođenoj planskoj privredi. Riječ je o svojevrsnom organiziranom »natjecanju bez tržišta«, koje sustavno izmiče tlo pod nogama svim institucijama koje

\footnotetext{
${ }^{4}$ Model o kojem je riječ izvorno je osmišljen kasnih osamdesetih i ranih devedesetih godina 20. stoljeća u laboratorijima i predavaonicama Massachusetts Institute of Technology i Harvard Business School. Njegove su menadžerske instrumente, poznate pod engleskim nazivima Business Process Reengineering, Total Quality Management, Benchmarking, Balanced Scorecard i Change Management potom pomogli proširiti ekonomski savjetnici iz tvrtki McKinsey, Accenture i Boston Consulting Group. Svi su ti instrumenti lako prepoznatljivi i u svojim izvedenicama primjenjivanim u akademskom kontekstu, gdje također umnogome počivaju na upotrebi računalne programske podrške i posvemašnjoj kvantifikaciji.
} 
bi svojom autonomijom trebale predstavljati protutežu takvom načinu organizacije društva. Jedno od tih područja prethodno velike autonomije bilo je upravo područje akademskog rada. Pretpostavka da će on i u novim okolnostima destabilizacije društva imati svoju prijašnju ulogu, ako se njegova nekadašnja unutarnja autonomija jednostavno zamijeni izvanjskom »totalnom kontrolom«, jedna je od većih zabluda danas globalno proširenoga menadžerskog načina razmišljanja.

Kolonizacija akademske zajednice ekonomijom. Uz već spomenutu društvenu konstrukciju »elitnosti« i »izvrsnosti«, Münch na stranicama svoje knjige detaljno razlaže različite aspekte i posljedice uvođenja »strateškog upravljanja« na sveučilište te uzroke i posljedice načina na koji je Homo academicus postao Homo oeconomicus, pridonoseći općoj kolonizaciji znanstvenog područja ekonomskim preokupacijama. Akademski sustav zapravo je u svojoj ukupnosti postao dijelom hegemonijski postavljenog ekonomskog područja, od kojeg se više uopće ne može razgraničiti i »slijediti svoje zakonitosti«, kao što to je to bio slučaj u klasičnom shvaćanju funkcionalno diferenciranog društva.

Možda se, kaže Münch, nije vodilo dovoljno računa o tome da je funkcionalno razgraničenim područjima - da bi očuvala željenu autonomiju - potrebna institucionalna zaštita: u slučaju znanstvenog rada, ona je uklonjena pod krinkom instrumentalnog »poboljšanja« akademske poduke. Stoga je, smatra Münch, umjesto u smislu luhmannovski funkcionalno diferenciranih sustava, danas bliže stvarnosti govoriti o bourdieuovskim poljima, u kojima se stalno odvijaju borbe za položaj $\mathrm{u}$ društvenom prostoru.

U tom kontekstu, materijalne se borbe vode oko osiguravanja vlastitog položaja u polju, a simboličke služe definiciji situacije i oblikovanju samih pravila igre. Prema Münchu, ekonomsko utemeljivanje akademske poduke i znanstvenog istraživanja stoga nije nikakva neizbježna »modernizacija« navodno »zastarjele« institucije nego simboličko preuzimanje i poništavanje cijeloga prethodno poznatog akademskog polja. U novim okolnostima, uzuse tog polja zamjenjuje logika ekonomskog razmišljanja, koju zastupa jednostrana ekonomska savjetnička elita (Fourcade, 2006): taj je ekonomistički način razmišljanja pretvorio sveučilišta u poduzeća i doveo do promjene habitusa odlučujućih aktera.

Novi $i$ stari habitusi. U sveučilištu vođenom po uzusima poduzeća, rektori su se pretvorili u korporacijske rukovoditelje, a znanstvenici u svojevrsne akademske poduzetnike. U središtu rasprave sada su litanije o poslovnoj uspješnosti sveučilišnog pogona: u navodnom interesu »transparentnog « prikazivanja situacije investitorima (u ovom slučaju apstraktnom »javnom interesu«), sveučilišta sve više troše na računovodstvo i marketing, a znanost prezentiraju ponajprije kroz brojke koje svjedoče o uspjesima ustanove. Ta igra brojki međutim postupno postaje stvarnost sui generis, sve udaljenija od stvarnih odnosa u društvu i u samom akademskom području.

Kad je o znanstvenicima riječ, akademski habitus starije generacije - koji podliježe bourdieuovskoj histerezi - postaje deplasiran i ta se generacija postupno povlači u unutarnju emigraciju. Mladi pak prihvaćaju nova pravila igre i prilagođu- 
ju im svoj habitus: njima je posve normalno vidjeti akademski svijet kao poslovni okoliš, u kojem više nisu najvažniji znanstvena spoznaja, čast vlastite discipline i priznanje akademske zajednice, nego prikupljanje bodova koji podebljavaju račun akademskog napredovanja i mogu se pretvoriti u ekonomski kapital. Poduzetnički habitus tako postaje jedini mogući habitus i u akademskom svijetu: sve se mora tržišno postaviti, pa tako uspješno »prodati« i samoga sebe (Bröckling, 2007). U tom svjetlu, objavljivanje u časopisima s visokim čimbenikom odjeka nipošto ne treba promatrati kao posljedicu znanstvene ambicioznosti nego kao vrhunski čin konformizma u ekonomski postvarenom polju znanosti.

»Upravljanje kvalitetom « ili osiromašenje znanja? Podjednako su zanimljiva i poticajna Münchova objašnjenja učinaka senzacionalističkog pristupa medija vanjskim znacima navodne znanstvene uspješnosti kroz tržišno iskoristive inovacije i patente, kao i analize značajki shvaćanja obrazovanja kao javnog dobra naspram »bolonjskom« shvaćanju obrazovanja kao statusnog simbola i sredstva za povećanje zaposlenosti.

Ipak, s obzirom na to da se ovaj osvrt objavljuje u sociološkom časopisu i da je u hrvatskoj sociološkoj zajednici aktualna rasprava o kriterijima znanstvenog napredovanja na temelju objava u međunarodno indeksiranim časopisima, možda nije neprimjereno posvetiti nešto širi prostor prenošenju Münchovih zamjedbi povezanih upravo s učincima »upravljanja kvalitetom« u području sociologije, koja je i autorova matična disciplina.

$\mathrm{U}$ tom smislu, barem u hrvatskom kontekstu, nije nevažno ni to što se Münchova pozicija u raspravi o akademskoj vrijednosti objavljivanja u međunarodno indeksiranim časopisima ne može dovoditi u pitanje argumentima osobne naravi. Riječ je, naime, o upravo umirovljenom profesoru, čija je ukupna djelatnost bila iznimno zapažena ne samo na nacionalnom govornom području, nego i na međunarodnom planu. Između ostaloga, Münch je bio suurednik i autor važnih priloga u već klasičnom zborniku o mikro-makro poveznici (Alexander i dr., 1987), a njegove nove knjige (Münch, 2009b, 2012) - upravo kao i niz prijašnjih - rado objavljuju vodeći izdavači na engleskom govornom području. ${ }^{5}$

Isto tako, prije rekapitulacije Münchovih zamjedbi o tome kako vrednovanje zasnovano na objavama u visoko rangiranim međunarodnim časopisima osiromašuje sociološku imaginaciju i društvenu korisnost sociološkog znanja, potrebno je iznijeti i dva općenita autorova zaključka koja bi zacijelo iznenadila mnoge kreato-

\footnotetext{
${ }^{5}$ Münchove jednoautorske knjige objavili su na engleskom jeziku Routledge \& Kegan Paul, Nelson Hall, Praeger, Rowman \& Littlefield i Palgrave Macmillan. Članci su mu, među ostalim časopisima na engleskom jeziku, objavljivani u American Journal of Sociology i Sociological Theory, a uredničke knjige, priloge u zbornicima i enciklopedijske natuknice u izdanjima nakladnika poput University of California Press, Elsevier, Pergamon, Sage, Wiley-Blackwell, Polity, Columbia University Press i Ashgate. Prije umirovljenja, Münch je objavio 36 jednoautorskih monografija, 6 uredničkih knjiga, 72 članka u časopisima, 110 poglavlja u knjigama, te 20 enciklopedijskih članaka.
} 
re aktualnih obrazovnih i znanstvenih politika diljem svijeta, pa tako i u Hrvatskoj. $\mathrm{Na}$ temelju vlastitih analiza i prijašnjih spoznaja drugih autora, Münch naime dovodi u pitanje temeljna polazište aktualnih vrednovanja akademske kvalitete: ono o osobitoj vrijednosti objavljivanja u »časopisima s međunarodnom recenzijom«, kao i ono o osobitoj vrijednosti »internacionalizacije« uopće.

Stupovi »revizijskoga društva«. U skladu s izrečenim, jasno je da Münch ne pristupa objavljivanju u »časopisima s međunarodnom recenzijom«s danas uobičajenog motrišta koje unaprijed pretpostavlja doprinos takve prakse znanstvenoj vrijednosti objava. Umjesto toga, autor međunarodni recenzijski postupak vidi kao dio četiriju stupova na kojima počiva »sustav totalne kontrole«, opisan u radovima Michaela Powera $(1997,2008)$. Riječ je o postupcima koji se diljem svijeta često označavaju engleskim izrazima peer review, benchmarking, evaluation i ranking, a koji svi zajedno čine osnovu »revizijskoga društva« (audit society) i njegovih »verifikacijskih rituala«. ${ }^{6}$ Prema Münchu, takvo društvo potiče »kulturu nepovjerenja« suprotnu prethodnim dobrim običajima akademske zajednice: u novom okruženju, recenzijski postupak vodi »normalizaciji« i uprosječivanju znanstvenih spoznaja, a ne »izvrsnosti« $\mathrm{i} »$ inovativnosti«.

Münch smatra da, prije svake detaljnije rasprave o njegovim prednostima i nedostacima, valja shvatiti da »režim peer reviewed journals« (Hirschauer, 2004) svoje postojanje i stabilnost duguje dvjema pretpostavkama: (1) efektivnoj prisili da se u takvim časopisima objavljuje, te (2) uvjerenju da će objavljivanje u njima povećati kvalitetu objava. Potonje je - nastavlja Münch - doista točno: nema sumnje da režim o kojem je riječ povećava kvalitetu objavljenih pojedinačnih priloga, ali ne i njihovu znanstvenu kreativnost i izvornost, koja se zapravo tim režimom sustavno isključuje kao »nedisciplinirana« i »anormalna«. Mladi znanstvenici, naime, brzo uče pravila igre i konformistički se prilagođuju očekivanjima recenzenata: prednost stoga daju projektima niskog rizika i metodološki rafiniranim radovima, koji međutim ne odgovaraju na doista znanstveno zanimljiva pitanja.

U Sjedinjenim Američkim Državama, gdje su se mladi istraživači prije susreli s tim sustavom, već je uvriježena praksa prema kojoj najviše vremena ulažu u konstrukciju baze podataka prikladne da bi se iz nje u sljedećih deset godina

\footnotetext{
${ }^{6} »$ Revizija« je tek jedan od mogućih prijevoda engleskog pojma audit, za koji Bujas (2005) kao hrvatske ekvivalente nudi $\mathrm{i}$ »službeno ispitivanje«, »revizija računa« te figurativno »polaganje računa«. Indikativno je da pojam potječe iz svijeta financija, a danas se upotrebljava u znatno širem spektru aktivnosti »menadžerskog kontrolinga«. Za pojam peer review u hrvatskom se upotrebljavaju uvriježeni izrazi »stručna recenzija«, "znanstvena recenzija« ili pak samo »recenzija«. Engleski pojam peer review upotrebljava se često u izvorniku, pretpostavljivo jer sadržava konotacije koje hrvatski pojam »recenzija« nužno ne pokriva (podrazumijeva se recenzija osoba djelatnih u istom području znanosti, kao i to da je recenzija anonimna). Ranking i evaluation prevode se na hrvatski bez poteškoća kao »rangiranje« i »vrednovanje«, a pojam benchmark se zasad najčešće ostavlja na engleskom izvorniku (njegovo podrazumijevano značenje jest ono »mjerila«, "polazišta«, »repera«, »standarda«).
} 
»izvlačili« predlošci za pokušaje objavljivanja u što je moguće više rangiranim časopisima. O kojim se znanstvenim temama radi pritom je od drugorazrednog značenja: istraživačka pitanja prilagođuju se značajkama prikupljenog skupa podataka, koji se potom pokušava metodološki besprijekorno obraditi. ${ }^{7}$ Sve to dovodi do »normalizacije znanja«, odnosno smanjenja teorijske i istraživačke radoznalosti, te odustajanja od bavljenja pitanjima koja izlaze iz unaprijed zacrtanoga tematskog i disciplinarnog okvira. Ukratko, znanje kojim naposljetku rađa režim peer reviewed journals bliže je strukovnom nego znanstvenom.

Iluzija o internacionalizaciji. Sličnim iznevjerenim očekivanja rađaju i nade koje se polažu u »internacionalizaciju« kao sredstvo napretka znanosti. Zaključci analiza brojnih autora koje navodi Münch pokazuju da rangiranja zasnovana na »međunarodnoj citiranosti« ne vode prema »međunarodnom znanstvenom tržištu«, nego zapravo predstavljaju jednostavnu dominaciju jednoga nacionalnog tržišta u odnosu na druga. Znanstvenici i ustanove iz SAD-a svoj hegemonijski položaj pritom ne zasnivaju na pretpostavljenoj kvaliteti vlastitih akademskih nastojanja nego na gusto prepletenoj i za druge prilično zatvorenoj mreži časopisa i citatnih kartela (Paasi, 2005).

Pridoda li se integriranom američkom tržištu (kakvo ne postoji u Europi) citatni potencijal drugih zemalja engleskoga govornog područja, postaje jasno zašto znanstveni članak američkog autora ima do 30 puta više izgleda biti citiranim od ma kako kvalitetnog rada nekoga njemačkog autora. Nije pritom riječ samo o tome da američki autori najviše citiraju druge američke autore (Deutsch, 1954; Frame i Narin, 1988; Bookstein i Yitzhaki, 1999; Herrera, 1999; Moed 2005), nego i tome da teme i pristupi izvan monokulturno definirane apsorpcijske moći citatnog tržišta jednostavno nemaju prođu: primjerice, u SAD-u cvate ekonomska sociologija, kojoj međutim nedostaje razumijevanje i uža povezanost s nasljeđem Marxove, Weberove i Durkheimove misli u području. Isto tako, u literaturi objavljivanoj u SAD-u uzaludno se nadati recepciji Luhmannove teorije sustava.

Odnos akademskog »uvoza" $i$ »izvoza«. Takvo stanje nipošto nije poticajno za napredak humanističkih i društvenih znanosti, jer bi »uvoz« znanja iz drugih kultura u njima trebao biti jednako važan kao i »izvoz« vlastitih spoznaja u dru-

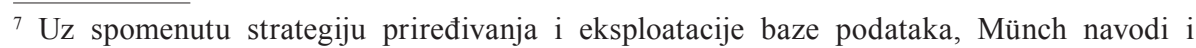
druge načine kojima se mladi socijalizirani u režimu peer reviewed journals služe da bi osigurali trajnije mjesto $\mathrm{u}$ akademskom pogonu. Riječ je o pristajanju na pravila igre, s motivom maksimizacije profita. Pod engleskim nazivom gaming the system kriju se tako prakse i načini samoorganizacije kao što su »taktika kriški salame«, mreže autora, karteli za citiranje, ekstremna specijalizacija, "plivanje u matici«, standardizacija prakse objavljivanja, strateško citiranje, prijevara, krivotvorenje rezultata i slično (Frey, 2008; Binswanger, 2010: 154-173). Dio prakse objavljivanja postala je zahvala recenzentima na konstruktivnoj kritici i detaljan izvještaj o izmjenama obavljenim na zahtjev recenzenata. Posebna vještina pritom postaje ispunjavanje nerijetko proturječnih zahtjeva različitih recenzenata na način da članak na koncu ipak bude prihvaćen za objavljivanje. 
ge kulture. Postavi li se kriterij »internacionaliziranosti« časopisa na drugi način, postaje jasno koliko je aktualan sustav američke hegemonijske prevlasti zapravo provincijalan i koliko ne teži širenju vlastitih znanstvenih obzora. ${ }^{8}$ Ta vrsta nereflektirane hegemonije - kojoj se zbog nedostatka javne znanstvene rasprave može odreći akademsku legitimnost - vodi znanost i visoko obrazovanje u slijepu ulicu dogmatizacije. Usto, citatna provincijalnost koja postaje »međunarodno mjerodavna«, rađa neizbježnim posljedicama i u drugim sferama društva. ${ }^{9}$

Društvena uloga nacionalnih sociologija. Budući da je sociologija društvena znanost, i to takva koja - uz mogućnost izgradnje apstraktnih modela - proučava društvene pojave u obliku u kojem one postoje na određenom mjestu i u određenom vremenu, postavlja se pitanje kako se može othrvati pritiscima koji efektivno izmiču tlo pod nogama teorijskim, kritičkim i društveno angažiranim oblicima rada u polju.

Münch smatra da je današnja situacija gotovo nerješiva. Tvorci njemačke znanstvene politike već su krenuli u smjeru koji vodi naglašavanju vrijednosti objava u režimu peer reviewed high impact journals, što znači da će postupno nestajati oblici objavljivanja u kojima se uopće mogu obrađivati teme značajne za njemačko društvo. One, naime, najvećim dijelom nisu zanimljive recenzentima i ciljnoj akademskoj publici »međunarodnih« časopisa, koji izlaze na engleskom

${ }^{8}$ Uzme li se kao stupanj »internacionaliziranosti« pojedinog časopisa količina navedene literature »uvezene« iz drugih zemalja, pokazuju se drastične razlike između vodećih američkih (čitati: »svjetskih«) i vodećih njemačkih društvenoznanstvenih časopisa. U 2006. godini, prema podatcima Institute for Scientific Information (ISI), American Journal of Sociology (AJS) i American Sociological Review (ASR) imali su 20 do 44 puta veću citatnost od Kölner Zeitschrift für Soziologie und Sozialpyschologie (KZSS) i Zeitschrift für Soziologie (ZfS). Međutim, u člancima objavljenim u ASJ i ASR citiralo se po pravilu između $90 \%$ i $100 \%$ američke autore, a u člancima objavljenim u KZSS i ZfS bilo je između 40\% i 70\% citata nenjemačkih autora. Münchova analiza dvaju oglednih članaka iz brojeva ASR i ZfS za veljaču 2008. pokazuje, primjerice, da su u američkom članku samo 3 od 112 referenci neameričke (i da je u tom slučaju riječ o citatima prijevoda na engleski klasika poput Bourdieua, Durkheima i Luckmanna). U njemačkom se pak članku 39 od 59 navoda referenci odnosi na literaturu na engleskom jeziku, što bi značilo da je njegov stupanj »internacionaliziranosti« 24 puta veći od američkog (naime, »internacionaliziranost« američkog članka - mjerena otvorenošću prema stranoj literaturi - bila bi u ovom slučaju vrlo skromnih $2,7 \%$, a njemačkoga čak $66 \%$ ).

${ }_{9}$ Primjer negativnog učinka dogmatizirane znanosti u širem društvenom kontekstu može biti tridesetogodišnja globalna hegemonija Nobelovom nagradom ovjenčane ekonomske misli Čikaške škole, koja je dovela ne samo do sveopće »ekonomizacije« sveučilišnog pogona nego i do najveće ekonomske krize u posljednjih osam desetljeća. Prema Münchu, predstavnici te škole svoju akademsku dominaciju mogu zahvaliti upravo ulozi američkih high impact journals i gusto postavljenim citatnim mrežama koje daju težinu prijedlozima za Nobelovu nagradu. Sve se to odvijalo u okviru američke prevlasti unutar Social Science Citation Index (SCCI) i Šangajskog rangiranja, dakle u kontekstu u kojem si američki znanstvenici mogu dopustiti provincijalnost i za nju - paradoksalno - biti ovjenčani međunarodnim priznanjima. 
jeziku. Štoviše, nakon uspostave novih pravila, znanstvenici će se - kao racionalni akteri - okrenuti onom tipu objava koje maksimiziraju akademski profit, što znači da će i sami pridonijeti vlastitoj postupnoj marginalizaciji i smanjenoj društvenoj relevantnosti discipline u kojoj djeluju.

Jednu od rijetkih iznimaka od tog pravila predstavljaju napori na razmeđu - burawoyevskim terminima rečeno - »profesionalne« i »javnopolitičke« sociologije, povezani sa zapaženim sudjelovanjem njemačkih sociologa u istraživanjima promjena životnih okolnosti koje sa sobom donose procesi globalizacije i europeizacije. Ti se napori odvijaju u snažno internacionaliziranom istraživačkom okolišu koji dobrim dijelom financira Europska unija, tako da se većina njihovih rezultata objavljuje u zbornicima i časopisima na engleskom jeziku. Bez obzira na to, u tom kontekstu ipak dolaze do izražaja analize specifično njemačkog načina organizacije kapitalizma i socijalne države, što se inače ne bi moglo očekivati od istraživačkih objava u matici međunarodno recenzirane časopisne produkcije.

Prema Münchu, valja stoga snažno podržati pojavu tijela poput European Consortium for European Sociological Research i časopisa European Sociological Review te druge slične napore na stvaranju gušće mreže za objavu rezultata specifično europskih empirijskih istraživanja. No, to ne rješava ozbiljne probleme koje stoje pred budućim objavljivanjem radova u području kritičke i teorijske sociologije, koji predstavljaju možda najveći dosadašnji doprinos njemačke društvenoznanstvene misli povijesti discipline.

Problemi kritičke $i$ teorijske sociologije. O mogućnosti objavljivanja teorijskih radova i jednoautorskih monografija u budućnosti će, čini se, odlučivati tek mogućnost postizanja odgovarajućih velikih brojki, a u tom je kontekstu njemačka znanost unaprijed hendikepirana $\mathrm{u}$ odnosu na one na engleskom govornom području. Naime, dok brojnost profesora i način organizacije američkog sveučilišta, omogućuju i postojanje znanstvenika koji ponajprije objavljuju u časopisima, kao i autora poznatih pod nazivom book people, u Njemačkoj tako nešto - već slijedom igre brojki - neće biti moguće. ${ }^{10}$

Krajnji ishod takvoga stanja već je poprilično jasan: Münch napominje da je preporuka njemačkih znanstvenih vlasti prema kojoj treba pisati više međunarodno recenziranih časopisnih članaka, u mlađih autora već urodila očitim nedostatkom

\footnotetext{
${ }^{10}$ Münch navodi da American Sociological Association (ASA) danas broji više od 14.000 članova (ili čak 22.000, ako se uzmu u obzir članovi pojedinih sekcija koji nisu u službenom članstvu ASA-a). Deutsche Gesellschaft für Soziologie (DGS) broji, dotle, samo nešto više od 1800 članova. Godišnje kongrese ASA-a posjećuje više od 6000 članova, a udruga izdaje deset časopisa. Kongresi DGS-a su dvogodišnji s najviše do 2200 sudionika, a udruga je do 2010. godine izdavala tek svoj strukovni bilten. U skladu s navedenim brojkama, a da se o veličini i integriranosti tržišta engleskog govornog područja i ne govori, američki sociolozi imaju znatno veću priliku pronaći za sebe odgovarajuću tržišnu nišu, čak i kad se bave specijalizacijama izvan matice discipline.
} 
koncentriranosti potrebne za pisanje knjiga. Upitna je i dosadašnja raznolikost vrsta objava u području sociologije koje su u Njemačkoj svjedočile ne samo o razgranatosti nego i društvenoj relevantnosti discipline. ${ }^{11}$

S druge strane, pitanje je koliko će prelazak na »časopisni režim« poboljšati mjesto njemačkih ustanova na Šangajskoj listi stotinu najvidljivijih ustanova u društvenim znanostima, gdje 2010. godine još uvijek nema niti jednoga sveučilišnog odsjeka iz zemlje i tradicije koja je iznjedrila Maxa Webera, Georga Simmela, Niklasa Luhmanna i Jürgena Habermasa.

Visoka cijena časopisnog prestrojavanja. Naglasak znanstvene politike na člancima objavljivanim u časopisima s međunarodnom recenzijom umnogome će utjecati na budućnost njemačke sociologije. Münch smatra da će takvo usmjerenje poremetiti ne samo dosadašnju ravnotežu hermeneutičkih i prirodoznanstvenih metodoloških sastavnica discipline (u korist potonjih), nego dovesti do promjena u svakodnevici dosad vrlo dobro uhodanoga akademskog pogona. U novim se okolnostima može očekivati da nitko više neće imati vremena za pisanje prikaza knjiga, leksikonskih članaka i enciklopedijskih priloga, udžbenika i priručnika, monografija, priloga u zbornicima sa znanstvenih skupova ili novinskih eseja. Stručna izvješća koja su plod istraživanja za zajednicu i projekata javne politike neće više biti moguće ni spominjati kao vrijedan doprinos društveno relevantnoga sociološkog rada.

Uzme li se u razmatranje i širi akademski kontekst, postaje jasno da će sve što se dosad radilo dobrovoljno, u sustavu zasnovanom na istraživačkoj i nastavničkoj strasti, profesionalnoj autonomiji i kolegijalnosti, u skoroj budućnosti postati tek predloškom za poticaje i sankcije koje stižu izvan samog sustava. Prema Münchu,

${ }^{11}$ Pilot-istraživanje njemačkog Savjeta za znanost (Wissenschaftsrat, 2008) pokazalo je da je u njemačkoj sociologiji u razdoblju između 2001. i 2005. godine objavljeno 42,5\% priloga u zbornicima, 34,4\% časopisnih članaka, 7,3\% monografija, $6,8 \%$ zbornika radova i 6,3\% prikaza. Časopisnih članaka je bilo ukupno 1000, od čega je 375 objavljeno u peer reviewed journals. U ukupnom broju objava je, dakle, bilo razmjerno malo one vrste (»međunarodno recenzirani časopisni članak«), koju će ubuduće favorizirati njemačka znanstvena politika. Da takvi članci dosad nisu bili osobito važni, pokazuje i nalaz da gotovo dvije trećine referenci u Zeitschrift für Soziologie u 2006. godini nisu bili časopisni članci (Hornbostel, Klingsporn i Ins, 2008). Analiza strukture društvenoznanstvenih radova u njemačkim časopisima nagrađenih priznanjem zaklade Thyssen u prvih šest godina prvog desetljeća 21. stoljeća, pokazala je sljedeće: nagrađeno je $57,7 \%$ (u apsolutnom broju 14) empirijsko-kvantitativnih, 26,9\% (7) empirijsko-kvalitativnih, $11,5 \%$ (3) teorijskih i društvenopovijesnih te 3,9\% (1) metodoloških radova (Alber, Fliegner i Nerlich, 2009). Zbog novog naglaska znanstvene politike, i u tom se pogledu može očekivati stanovito smanjenje raznolikosti profila objava, $i$ to na daljnju štetu radova u području teorije i povijesti ideja. Konačno, nije naodmet napomenuti da je citirano pilot-istraživanje njemačkog Savjeta za znanost (Wissenschaftsrat, 2008) pokazalo i to da je između 2001. i 2005. godine tek $15,6 \%$ radova nastalih u polju njemačke sociologije bilo objavljeno izvan njemačkoga govornog područja. Novi naglasak na takvim objavama također će dovesti do promjene prethodno postojećih odnosa u struci. 
cjelokupna će njemačka akademska zajednica - ne samo ona djelatna u društvenim znanostima - skupo platiti prelazak s dosadašnjega kolegijalnog sustava na model primarnih činitelja »izvrsnosti«. No, u području sociologije valja osobito imati na umu da "profesionalna sociologija» američkog predznaka svoju visoku teorijsku i metodološku strogost često plaća praktičnom irelevantnošću spoznaja i općenitom društvenom beznačajnošću.

Pouke Münchove knjige. Što se, na koncu, može naučiti od iznimno dobro dokumentirane i znanstveno suvereno napisane Münchove knjige o »akademskom kapitalizmu«, koji ne kuca samo na vrata njemačke, nego i hrvatske akademske zajednice? Kakve mogu biti pouke Münchovih analiza novoga akademskog poretka u sociološkoj zajednici čija strukovna udruga broji tek dvjestotinjak članova i članica te sukladno tome može računati s još manjim mogućnostima na globalnom akademskom tržištu nego kad je riječ o njemačkim kolegama i kolegicama?

Prva pouka, čini se, trebala bi biti da ta zajednica - ne samo zbog sebe same, nego i zbog društva u kojem djeluje - ne bi smjela pri aktualnim zakonskim izmjenama zauzeti položaj onih intelektualaca koji su - baumanovski rečeno ponajprije »interpretatori« društvene stvarnosti, a ne »zakonodavci« na temelju čijeg se akademskog legitimiranja ta stvarnost ponekad drastično mijenja. Uz daljnje interpretativne analize, sada je vrijeme i za djelovanje na društvenoj sceni, uz ostalo i davanjem vlastitog priloga raspravama o kriterijima napredovanja u svom akademskom polju, kao i o načinu organizacije akademskog pogona u zemlji općenito.

Druga pouka Münchovih analiza mogla bi biti spoznaja da male akademske zajednice ne moraju nužno biti samo nepotističke i mentalno korumpirane, nego da zbog svoje nedostatne veličine mogu pružiti osnovu za način djelovanja drukčiji od danas uobičajenoga. Prema Münchu, u zemljama u kojima se naglašava važnost i vrijednost objava u časopisima s međunarodnom recenzijom do preporuka ove vrste između ostaloga dolazi zbog nepreglednog obilja članaka koji kolaju akademskim tržištem, što stvara potrebu za ponajprije kvantitativnim načinom njihova vrednovanja. $^{12}$

Mala strukovna zajednica, u kojoj je broj objava ograničen i pregledan, postupak vrednovanja morala bi moći temeljiti na kriterijima koji uzimaju u obzir supstancijalnu a ne samo formalnu procjenu kvalitete sadržaja objava, kao i ukupan znanstveni i društveni doprinos pristupnika ili pristupnice. Pretpostavke takvog postupka su, dakako, visoka strukovna kompetentnost i etičnost izbornih povjerenstava, što je područje u kojem svakako može doći do pozitivnih pomaka, pogotovo ako se u njihov rad uključe članovi i članice koji djeluju u drugim akademskim zajednicama.

${ }^{12}$ Uvjerenje u učinkovitost $\mathrm{i}$ smislenost se, pak, temelji na podatku da su kvantitativno obrađivani radovi prethodno već prošli strogu recenzentsku kontrolu i postigli kvalitetu koja se može zajamčiti čimbenikom odjeka časopisa u kojem su objavljeni. 
Konačno, treća pouka Münchove knjige mogla bi biti da zemlja veličine i međunarodnog položaja Hrvatske ne bi smjela dopustiti efektivno poništenje društvene uloge akademskog bavljenja sociologijom, ako ni zbog kojeg drugog razloga onda stoga što bez kompetentne društvene analize ne može konkurirati niti na razvojne fondove Europske unije. Upravo kao što to sugerira Münch, sudjelovanje u znanstvenim praksama i politikama na europskoj razini, jedan je od rijetkih načina na koji sociologije na neengleskim govornim područjima mogu postići stanovitu međunarodnu vidljivost i povećati svoju društvenu korisnost.

Sigurno je da, uz iznesene, postoji i niz drugih - vjerojatno manje idealistički intoniranih - postupaka kojima se moguće suprotstaviti negativnim posljedicama globalne ekspanzije načela »akademskog kapitalizma«. No, da bi se ti postupci mogli osmisliti potrebno je najprije dobro razumjeti kakve sve opasnosti ta ekspanzija donosi: Münchovu knjigu stoga svakako valja preporučiti pozornosti hrvatskih nakladnika.

\section{LITERATURA}

Alber, Jens, Fliegner, Florian i Nerlich, Torben (2009). Charakteristika prämierter Forschung in der deutschsprachigen Sozialwissenschaft. Eine Analyse der mit dem Preis der Fritz Thyssen Stiftung ausgezeichneten socialwissenschaftlichen Aufsätze 1981-2006. Wissenschaftszentrum Berlin für Sozialforschung. WZB Discussion Paper. http://bibliothek.wzb.eu/pdf/2009/i09-201.pdf.

Alexander, Jeffrey C., Giesen, Bernhard, Münch, Richard i Smelser, Neil J. (ur.) (1987). The Micro-Macro Link. Berkeley, Los Angeles i London: University of California Press.

Beyer, Jürgen (2006). Pfadabhängigkeit. Über institutionelle Kontinuität, anfällige Stabilität und fundamentalen Wandel. Frankfurt am Main i New York: Campus.

Binswanger, Mathias (2010). Sinnlose Wettbewerbe. Warum wir immer mehr Unsinn produzieren. Freiburg: Herder.

Bookstein, A[braham] i Yitzhaki, M[oshe] (1999). »Own-language preference: A new measure of 'Relative Language Self-citation'", Scientometrics, 46 (2): 337-348. doi: 10.1007/BF02464782

Bröckling, Ulrich (2007). Das unternehmerische Selbst. Frankfurt am Main: Suhrkamp.

Bujas, Željko (2005). Veliki englesko-hrvatski rječnik. 4. izd. Zagreb: Globus.

Deutsch, Karl W. (1954). »Is American attention to foreign research results declining?«, American Academy of Arts and Sciences (9 June, 1954).

Douglas, John A. (2007). The Conditions for Admission: Access, Equity and the Social Contract of Public Universities. Stanford, CA: Stanford University Press.

Duda, Dean (2002). Kulturalni studiji: ishodišta i problemi. Zagreb: AGM.

Etzkowitz, Henry (2003). »Innovation in Innovation: The triple helix of university - industry - government relations«, Social Science Information, 42 (3): 293-337. doi: 10.1177/05390184030423002 
Fourcade, Marion (2006). »The construction of a global profession: The transnationalization of economics«, American Journal of Sociology, 112 (1): 145-194. doi: $10.1086 / 502693$

Frame, J. Davidson i Narin, Francis (1988). »The national self-preoccupation of American scientists: An empirical review«, Research Policy, 17 (4): 203-212. doi: 10.1016/0048-7333(88)90049-2

Frey, Bruno S. (2008). »Evaluitis - eine neue Krankheit«, u: Hildegard Matthies i Dagmar Simon (ur.). Wissenschaft unter Beobachtung. Effekte und Defekte von Evaluationen. Wiesbaden: VS Verlag für Sozialwissenschaften, str. 125-140. doi: 10.1007/978-3-531-90863-2_8

Gibbons, Michael, Limoges, Camille, Nowotny, Helga, Schwartzmann, Simon, Scott, Peter i Trow, Martin (1994). The New Production of Knowledge: The Dynamics of Science and Research in Contemporary Societies. London, Thousand Oaks i New Delhi: Sage.

Gruening, Gernod (2001). »Origin and theoretical basis of New Public Management«, International Public Management Journal, 4 (1): 1-25. doi: 10.1016/ S1096-7494(01)00041-1

Hartmann, Michael (2006). »Die Exzellenzinitiative - ein Paradigmenwechsel in der deutschen Hochschulpolitik«, Leviathan, 34 (4): 447-465. doi: 10.1007/ s11578-006-0064-1

Herrera, Antonio J. (1999). »Language bias discredits the peer-review system«, Nature, 397: 467. doi: 10.1038/17194

Hirschauer, Stefan (2004). »Peer Review Verfahren auf dem Prüfstand. Zum Soziologiedefizit der Wissenschaftsevaluation«, Zeitschrift für Soziologie, 33 (1): $62-83$.

Hornbostel, Stefan, Klingsporn, Bernd i Ins, Markus von (2008). »Messung von Forschungsleistungen - eine Vermessenheit?«, Publikationsverhalten in unterschiedlichen wissenschaftlichen Disziplinen, Bonn, Diskussionspapier der Alexander von Humboldt-Stiftung, Nr. 12, str. 11-32.

Karabel, Jerome (2005). The Chosen: The Hidden History of Admission and the Exclusion at Harvard, Yale, and Princeton. Boston. Houghton Mifflin.

Lane, Jan-Erik (2000). New Public Management. London i New York: Routledge.

Lenhardt, Gero (2005). Hochschulen in Deutschland un in den USA. Deutsche Hochschulpolitik in der Isolation. Wiesbaden: VS Verlag für Sozialwissenschaften.

Liessmann, Konrad Paul (2006). Theorie der Unbildung. Die Irrtümer der Wissensgesellschaft. Wien: Zsolnay.

Liessmann, Konrad Paul (2008). Teorija neobrazovanosti: zablude društva znanja. Zagreb: Naklada Jesenski i Turk.

Moed, Henk F. (2005). Citation Analysis in Research Evaluation. Dordrecht: Springer.

Münch, Richard (2007). Die akademische Elite. Zur sozialen Konstruktion wissenschaftlicher Exzellenz. Frankfurt am Main: Suhrkamp.

Münch, Richard (2008). Die Konstruktion der europäischen Gesellschaft. Zur Dialektik von transnationaler Integration und nationaler Desintegration. Frankfurt am Main: Campus. 
Münch, Richard (2009a). Das Regime des liberalen Kapitalismus. Inklusion und Exklusion im neuen Wohlfahrtsstaat. Frankfurt am Main: Campus.

Münch, Richard (2009b). The European Regime of Liberal Democracy: Regulation, Law and Politics in the Multilevel System. London: Routledge.

Münch, Richard (2009c). Globale Eliten, lokale Autoritäten. Bildung und Wissenschaft unter dem Regime von PISA, McKinsey \& Co. Frankfurt am Main: Suhrkamp.

Münch, Richard (2011a). Akademischer Kapitalismus. Über die politische Ökonomie der Hochschulreform. Berlin: Suhrkamp.

Münch, Richard (2011b). Das Regime des Freihandels, Entwicklung und Ungleichheit in der Weltgesellschaft. Frankfurt am Main: Campus.

Münch, Richard (2012). Inclusion and Exclusion in the Liberal Competition State: The Cult of the Individual. London i New York: Routledge.

Paasi, Anssi (2005). »Globalisation, academic capitalism, and the uneven geographies of international journal publishing spaces«, Environment and Planning A, 37 (5): 769-789. doi: 10.1068/a3769

Power, Michael (1997). The Audit Society: Rituals of Verification. Oxford i New York: Oxford University Press.

Power, Michael (2008). »Research evaluation in the audit society«, u: Hildegard Matthies i Dagmar Simon (ur.). Wissenschaft unter Beobachtung. Effekte und Defekte von Evaluationen. Wiesbaden: VS Verlag für Sozialwissenschaften, str. 15-24. doi: 10.1007/978-3-531-90863-2_2

Rhoades, Gary i Slaughter, Sheila (2006). »Mode 3, academic capitalism and the new economy: Making higher education work for whom?«, u: Päivi Tynjälä, Jussi Välimaa i Gillian Boulton-Lewis (ur.). Higher Education and Working Life: Collaborations, Confrontations and Challenges. Amsterdam: Elsevier, str. 9-35.

Soares, Joseph A. (2007). The Power of Privilege: Yale and America's Elite Colleges. Stanford, CA: Stanford University Press.

Wissenschaftsrat (2008). Forschungsleistungen deutscher Universitäten und außeruniversitärer Einrichtungen in der Soziologie. Köln: Wissenschaftsrat. 